\title{
Disclosure levels of environmental accounting information and financial performance: The case of Vietnam
}

\author{
La Soa Nguyena and Manh Dung Tran ${ }^{a^{*}}$
}

${ }^{a}$ Hanoi University of Industry, Vietnam

${ }^{b}$ National Economics University, Vietnam

\section{H R O N I C L E \\ A B S T R A C T}

Article history:

Received: October 28, 2018

Received in revised format: No-

vember 18, 2018

Accepted: January 12, 2019

Available online:

January 12, 2019

Keywords:

Environment accounting

Information disclosure

Financial performance

Accounting information
This research is conducted for assessing the relationship between disclosure levels of environmental accounting information and financial performance. Data were collected from the firms listed in Vietnam from 2013 to 2017 , including the firms disclosed and the ones did not disclose the environmental accounting information. The study uses two regression models to investigate the relationship between environmental accounting information and return on assets. The results indicate that there was a close relationship between disclosure level of environmental accounting information and financial performance. In addition, there was a difference in terms of financial performance between the firms had not disclosed environmental accounting information and the ones disclosed the environmental accounting information.

\section{Introduction}

Globalization, international economic integration and trade liberalization have yielded outstanding trends in the modern world economy. The process of deepening, broadening and effective integration of Vietnam into the world economy has brought about great achievements for the country in general as well as firms in particular. Vietnamese firms have more opportunities to enter the global market and integrate deeper into the world financial market for accessing foreign capital inflows. However, countries in the world, especially in Western Europe and East Asia, have been investing heavily in green growth strategies. They are particularly interested in combating and removing access to markets of imported products that do not comply with the production process and do not meet the requirements of environmental protection. In that context, Vietnamese firms with stable and strong development need to pay attention to environmental and social responsibility apart from getting profits. Business activities have positive and negative impacts on the environment and vice versa, the environment also contributes to the advantages or disadvantages in production and business activities of the firms. Therefore, the

* Corresponding author.

E-mail address: manhdung@ktpt.edu.vn (M. D. Tran) 
accounting and information on revenue and environmental costs will help firms understand clearly the relationship between business activities of firms and the environment. Moreover, it will enhance the prestige and image of the business with domestic and foreign partners. This is also the reason for the business community in the countries participating in the Transpacific Partnership Agreement (TPP) for not ignoring the disclosure of information about activities and measures to protect environment.

Vietnam is a member of the TPP agreement, so the implementation and disclosure of environmental accounting information by Vietnamese firms is considered as a key factor. It is also a necessary condition helping firms improve competitive capacity and develop sustainably in the context of global economic integration. Circular No. 155/2015/TT-BTC issued by Ministry of Finance, effective from January $1^{\text {st }} 2016$, mandates public firms to publish some environmental information for sustainable development goal. In Vietnam, firms listed on the stock market are already aware of the importance of disclosure and transparency of environmental accounting information to the company's existence and development. However, this level is not really high and there are still differences between firms. Therefore, we conduct the project to confirm the relationship between the level of disclosure of environmental accounting information and financial performance of the company, thereby raising the awareness of the firms about the importance of disclosure of environmental accounting information. This study contributes to provide some directions and effective solutions to promote Vietnamese enterprises to implement and disclose environmental accounting information in the coming years.

\section{Literature Review}

In developed countries, environmental accounting has received the attention of both academics and business executives. Although officially mentioned in the guidelines on environmental accounting by the United Nations Commission on Sustainable Development (UNDSD) in 2001 and International Federation of Accountants (IFAC) in 2005, environmental accounting in reality has been investigated since 1970s and implemented in many firms in developed countries since the 1990s. In the field of research, scientific papers on environmental accounting appeared very early in the 1970 s, but it was not until the 1990s that there were more and more researches conducted, with 45 works, research papers on environmental accounting has been published each year on average. In particular, the period from 1997 to now is considered to be a boom period for studies related to environmental accounting (Ting, 2017). In addition to popular research such as the theoretical studies related to environmental accounting, research on how to apply practical accounting practices to businesses in different fields, research on the factors affecting the level of disclosure of environmental accounting information or the relationship between disclosure of environmental accounting information and business performance of firms are also of interest to scientists.

The research conducted by Al-Tuwaijri et al. (2004) provides an integrated analysis of the interrelations among (i) environmental disclosure, (ii) environmental performance, and (iii) economic performance. Based on the argument that management's (unobservable) overall strategy affects each of these corporate responsibilities, the research conjectures that prior literature's mixed results describing their interrelations may be attributable to the fact that researchers did not consider these functions to be jointly determined. After endogenizing these corporate functions in simultaneous equations models, this research obtained results that suggest "good" environmental performance could be significantly associated with "good" economic performance, and also with more extensive quantifiable environmental disclosures of specific pollution measures and occurrences.

The study conducted by Magness (2006) found that firms that maintain themselves in the public eye through press release activity disclose more information than other firms. However there is no evidence to suggest that disclosure content is moderated by financial performance. Firms that obtained external financing one year after the accident made more disclosure than other firms did. The significance of the external financing variable is evident when disclosure is restricted to discretionary or non-financial items, but disappears if the dependent variable represents mandatory financial items.

Boaventura et al. (2012) used a 15 year period data from 1996 to 2010. The sampling process obtained a set of 58 exclusively theoretical-empirical and quantitative articles that test the relationship between 
corporate social performance (CSP) and corporate financial performance (CFP). The main results in the theoretical field reinforce the proposed positive relationship between CSP and CFP and good management theory and demonstrate a deficiency in the explanation of the temporal lag in the causal relationship between CSP and CFP as well as deficiencies in the description of the CSP construct.

The research by Barakat et al. (2015) showed that the listed firms used corporate social responsibility initiatives to communicate social performance to their stakeholders. From the regression analysis, community involvement disclosure, products and customer disclosures and human resource disclosures were found to enhance corporate financial performance. The results also revealed a negative relationship between environmental disclosure and CFP, which indicates that disclosure of environmental impact information could be value destroying in Nigeria.

The study by Majeed et al. (2015) evaluated the factors affecting the level of disclosure of information about environmental and social responsibility of listed firms in Pakistan. The study was conducted with a sample of 49 firms with a report from 2007 to 2011. The study looked at factors including: board size, the degree of board independence, nationality and gender of the representative on the board, the degree of decentralization, the size and the profit of the business. Research shows that there was a positive and significant impact of the size of the board. The level of board independence, the degree of decentralization and the size of the business have a noticeable impact on the level of disclosure corporate social and environmental responsibility. The results also show the reverse relationship between the woman and the foreign representative to the level of disclosure of environmental information.

The study by Barakat et al. (2015) was carried out for characterizing and evaluating the activities of the extent of disclosure of environmental responsibility of firms in Palestine and Jordan. The research sample includes 101 firms updated by 2011. Research shows that the level of disclosure of environmental accounting information in firms in Jordan was higher than that of Palestinian firms in all aspects. However, compared to the western countries, the level of information disclosure of both countries was low. It means that firms in Jordan were interested in resources and commitment to the community compared to other firms in Palestine. To explain this difference, the study demonstrated that the legal system, the characteristics of external auditing firms and the characteristics of corporate governance had a positive relationship with the level of disclosure of information environmental responsibility of the business.

The study by Qiu et al. (2016) examined the link between a firm's environmental and social disclosures and its profitability and market value. The research found that past profitability drives current social disclosures. However, consistent with the existing evidence, this research did not find any relationship between environmental disclosures and profitability. Further, while prior literature has largely focused on environmental disclosure, the researchers found that it is the social disclosures that matter to investors and firms that make higher social disclosures had higher market values. Further analysis reveals that this link was driven by higher expected growth rates in the cash flows of such firms.

The study by Yang \& Liangb (2017) investigated accounting information disclosure of environmental accounting for the listed enterprises of paper printing and printing industry over the period 2013-2015. According to this study, many factors affect the level of disclosure of accounting information in the enterprise including the proportion of tradable shares, company size, the extent of liabilities, profitability, growth ability, whether through the ISO 14001 certification. The scale of enterprises, whether through the ISO 14001 certification and EDI is a significant positive correlation, and the regression results show that the ISO 14001 certification had more influence on the degree of environmental accounting information disclosure. This shows that the larger the company to strengthen the trust of investors, the more financing opportunities and the more disclose on environmental accounting information. Moreover, the company through the ISO certification, it is necessary to establish a good external image, internationally recognized, and urge them to enhance the environmental accounting information disclosure and improve the disclosure level.

The study by Hitt et al. (2017) was carried out for development of the idea of "stakeholder management" as it has come to be applied in strategic management. They recommend that traditionally the stakeholder approach to strategic management maintained several related characteristics that serve as 
distinguishing features. They also reviewed other works on stakeholder theory and suggested how stakeholder management affected the practice of management. In Vietnam, studies related to the disclosure of environmental accounting information can be referred to as researches of Nguyen (2016); Nguyen \& Tran (2017); Nguyen et al. (2017); Nguyen et al. (2018). Based on quantitative research method, these studies have investigated the factors affecting the disclosure levels of accounting information and have given some recommendations to improve environmental accounting in future. However, these studies are limited to explore and evaluate the impact of factors on the level of disclosure of environmental accounting information for that type of enterprise. Therefore, solutions to improve environmental accounting and improve the level of disclosure of environmental accounting information have not really convinced the enterprises, not to clearly see the effect of information disclosure environmental accounting. Research of Ho et al. (2017) implemented with 156 listed firms in Vietnam for the period 2012 - 2015. The results of this research indicate that efforts of environmental protection and activities would help to achieve higher financial performance in the same time and in the future as well. However, this study only refers to the environmental protection force without considering the aspect of disclosure of environmental accounting information.

Thus, in the past time, in the world and in Vietnam, there are a lot of studies on the factors affecting the level of disclosure of environmental accounting information as well as the relationship with financial efficiency. However, these studies have not really provided a convincing demonstration of the effectiveness of disclosure of environmental accounting information to firms, thereby encouraging firms to publish mandatory information and Voluntary with regard to the environment. Therefore, the research of the authors is really necessary, the above research is applied selectively but not duplicate.

\section{Theoretical Background and Research Hypotheses}

\subsection{Theory of Disclosure of Environmental Accounting Information}

Research views on environmental accounting argue that environmental accounting is judged in two aspects, accounting and environmental management. In addition to supporting internal decision making in the business operations of the business with the view to improving financial and environmental performance, environmental accounting also provides information outside the business to stakeholders such as banks, financial institutions, environmental management agencies, communities, etc. Thereby it helps businesses (i) Enhance competitive advantage due to green consumption of clean products, (ii) Change and increase the level of awareness and action of organizations and stakeholders on environmental issues in each company and the economy as a whole. Thus, the sufficient, timely and accurate information environmental accounting disclosure of firms listed on the stock market in Vietnam plays an important role not only for businesses, investors but also for state management agencies. To explain the disclosure of environmental accounting information of enterprises, we use the following theories as:

Theory of Legitimacy and Responsibility for Publicizing Environmental Accounting Information: Legitimacy Theory defined by Dowling \& Pfeffer (1975) states that a firm can exist when its value system is consistent with the value system of the larger social system in which it is located. Inheriting and developing the theory of legalization, Guthrie and Parker (1989) argue that the theory of legalization is related to the power of society. They believe that business enterprises in society must sign a social contract that managers agree to implement. The terms of this contract may be specified in terms of legal provisions or unspecified depending on the expectations of the social community. Legal theory explains the responsibility for implementing environmental accounting of enterprises as follows: (i) The necessity to implement environmental accounting derives from society, government's dissatisfaction and the pressure from demand of workers, consumers and stakeholders (ii) Environmental disclosure is a motivation for businesses to legitimize their activities, thereby promote their image that benefits them. Thus, disclosing public environmental information in annual reports is a strategic representation of the business. This strategy implies that the business is operating legally and has social responsibility. 
Relevant stakeholder theory and the responsibility to disclose environmental accounting information: The Stakeholder Theory is derived from the perspective of economic interests in all actions by the economist Freeman (Hitt et al., 2017). According to Freeman, all stakeholders are affected by all business behaviors, including shareholders, suppliers, customers, employees, competitors, social workers, lawmakers, academics, indigenous peoples, labor organizations, local administration and the government. Based on stakeholder theory, Ullmann (1985) explains that if a stakeholder controls an important source of business, the business will find a way to satisfy their needs. Environmental information disclosure is considered an effective governance strategy that addresses relationships and satisfies needs of stakeholders. On the other hand, the study by Chiu and Wang (2017) shows that return on equity (ROE) is positive and debt to equity ratio had a reverse relationship with the disclosure of information about the environment.

Signaling Theory and the responsibility to disclose environmental accounting information: Signal Theory suggests that asymmetric information between businesses and investors leads to adverse selection for investors. To avoid this situation, businesses voluntarily publish information and give positive signals to the market. According to this theory, the larger the business, the greater the imbalance of information (Guthrie \& Parker, 1989). In addition, higher-yielding firms will tend to publish more information to provide positive signals to investors about growth prospects, which will have a positive impact on stock prices of the business.

Relationship between cost and benefit and levels of environmental accounting information disclosure theory: The Cost Benefit Theory shows that the benefits of disclosure of environmental accounting information should be considered in relationship with the cost of creating and providing that information. Thus, the level of disclosure of environmental accounting information should be taken into consideration between the added benefits and the increased costs when performing this task.

\subsection{Measurement of Corporate Financial Performance}

Previous studies have suggested that the company's financial performance can be measured in either a measurement based on accounting or market-based.

Accounting based: Use accounting metrics such as return in assets (ROA), ROE or financial analysis of the company (Horváthová, 2012). These indicators may reflect the performance of the company at an overall level but do not observe the multinational characteristics of the company's production process. Several accounting-based measures have been used to assess financial performance including ROE and ROA (Nelling \& Webb, 2009; Simpson \& Kohers, 2002) using ROA and loan losses. The reason for using these three variables to measure financial performance is that these data are less likely to be manipulated, and are also the most commonly used measures for financial performance. But the inherent limitations of accounting based measures are that they only capture historical data on financial performance. Moreover, the data may be misleading by the different management perceptions and accounting procedures used by different firms.

Market based: Some studies use market metrics (Boaventura et al., 2012). Because the measure of market based financial performance avoids some accounting constraints as it shows future factors and focuses on market efficiency. These measures are less relevant to accounting procedures and are an indicator of the investor's choice to evaluate a company's ability to generate future profits. The use of market-based measures indicates that evaluating the financial performance of investors is a good measure of performance. However, the use of stocks as market-based measures of financial performance also have limitations. In addition, a number of studies have used both accounting data and market data (Ahmed \& Habib, 2015) with three variables such as ROA, stock market return, and Tobin's q. In addition, Nelling and Webb (2009) used stock returns as a dependent variable to measure financial performance. Simpson and Kohers (2002) argued that both accounting and market indicators can be applied to measure the financial performance of an enterprise, each of which depends on certain trends. 
3.3. The Profit Motive Theory and Relationship between Disclosure Level of Environmental Accounting Information and Financial Performance

According to the profit motive theory, investment in sustainable development in general and investment in environmental accounting disclosure in particular will change the financial results of the business in the future positive direction (Ullmann, 1985). For example, investing in transparency and disclosure of information related to environmental accounting will increase the image of the business with the community, with stakeholders, thereby increasing revenue, market share, or will attract more qualified and ethical staff to work at the unit, or reduce unwanted conflicts with stakeholders, or avoid legal troubles. Direct or indirect damage to the environment will likely result in the loss of credibility in the consumer's eyes (Simpson \& Kohers, 2002). In fact, customers have come and gone back to businesses that create a good image in the eyes of consumers about the sense of protection and preservation of the environment. Controlling and disseminating environmental information is one of the key elements of business credibility, which satisfy and strengthen the trust of stakeholders (Ali et al., 2004). At the same time, implementing environmental accounting also brings to the enterprise a noteworthy income such as: subsidies, bonuses from environmental protection investments, the difference from cost cutting advances in the process, minimizing waste disposal costs; proceeds from sales of waste materials, disposal of waste, etc. (Jamil et al., 2015).

Recently, studies related to corporate social responsibility in general and environmental responsibility in particular for corporate financial performance have measured the relationship between corporate social responsibility and performance. Research results indicate that corporate social responsibility can improve a company's competitiveness over the long term, implying a positive relationship between corporate social responsibility involvement and the financial performance of that enterprise (Qiu et al., 2016). Many empirical studies have found a similar relationship between environmental responsibility and financial performance (Al-Tuwaijri et al., 2004; Qiu et al., 2016; Simpson \& Kohers, 2002). Dowling \& Pfeffer (1975) defined profit as an important element in the disclosure of corporate environmental responsibility practices. Barakat et al. (2015) also found a meaningful relationship between environmental responsibility and financial performance. The study also argued that firms with good financial performance would have more resources. In order to deal with social problems, these two variables have the potential to influence one another. However, contradictory to this study, Waddock and Graves (1997) and Moore (2001) provide a summary of previous research findings on negative correlations, positive and non-correlated correlations. The studies also suggest that disclosure of social responsibility information would increase costs and reduce financial efficiency. In addition, Nelling and Webb (2009) argued that there was no relationship between social responsibility and financial performance. Therefore, to examine the relationship between the level of disclosure of environmental accounting information and the financial performance of listed firms in Vietnam, as well as how to consider the relationship, the following hypothesis is as proposed:

H1: There is a close relationship between the level of disclosure of environmental accounting information and financial performance of listed firms in Vietnam.

\subsection{Review Financial Performance of Listed Firms Disclosing Environmental Accounting Information to Other Listed Firms not Disclosing Environmental Accounting Information}

There is a lot of empirical supports for the view that firms would be fined if they saw business management in ways that conflict with social values. This is especially true when the conflict arises between pursuing organizational profits and the goal of environmental protection. Thus, one of the ways firms risk management in the process of operating and improving financial performance is to engage in socially and socially responsible behavior. Isanzu and Fengju (2016) investigated the effects of social responsibility on financial performance by comparing financial performance (ROA, ROE) through an average t-test of a sample of 50 firms social responsibility and 51 firms did not publish social responsibility, the results of social responsibility had the same impact on the financial efficiency and financial performance of firms that publish high social responsibility than the firms did not disclose social re- 
sponsibility. Poddi and Vergalli (2016) investigated the relationship between corporate social responsibility and corporate effectiveness (ROE, MVA, SIZE, INTA, ROCE, AGE) by analyzing the strategic graphs among the 100 non-public liability firms and 317 firms. The main results show that there were some differences in some economic indicators between firms that disclose social responsibility and firms that did not disclose corporate social responsibility. In order to better understand the relationship between social responsibility and financial performance of Vietnamese listed firms, the study examines the financial performance between the listed firms have disclosed environmental accounting information and listed firms did not disclose environmental accounting information to assess the impact of social responsibility on financial performance as well as the benefits that corporate social responsibility provided the listed firms with environmental accounting information in the context of Vietnam. Specifically, we give the hypothesis as

H2: There are financial performance differences between listed firms with disclosure of environmental accounting information and firms listed without environmental accounting information.

\section{Research Methodology}

\subsection{Data Collection}

Group 1: Listed Firms with Environmental Accounting Information: The selected firms must meet two criteria: (i) having a complete set of annual accounting data for the five years (2013 - 2017 (ii) Firms must disclose environmental accounting information in their annual reports. The final sample for this study was unbalanced table data, as shown in Table 1.

\section{Table 1}

Research Sample Statistics

\begin{tabular}{llccccc}
\hline \multirow{2}{*}{ No. Sectors } & \multicolumn{4}{c}{ Number of listed firms disclose environmental accounting } \\
& & \multicolumn{3}{c}{ information } \\
\cline { 3 - 6 } & & 2013 & 2014 & 2015 & 2016 & 2017 \\
\hline 1 & Agriculture - Forestry - Fishery & 1 & 6 & 12 & 14 & 25 \\
2 & Extractive & 5 & 12 & 14 & 16 & 27 \\
3 & Community utilities & 2 & 3 & 6 & 8 & 12 \\
4 & Construction and real estate & - & - & 5 & 6 & 11 \\
5 & Manufacturing & 2 & 4 & 9 & 14 & 30 \\
\hline \multicolumn{2}{c}{ Total } & 10 & 25 & 46 & 58 & 105 \\
\hline
\end{tabular}

Group 2: Listed firms do not disclose environmental accounting information: These firms must meet two criteria: (i) a complete annual accounting data sheet covering the five years (2013-2017). ii) Firms must correspond to the size, sector and time of listing with Group 1 firms.

\subsection{Variable Measurements}

\section{- Level of disclosure of environmental accounting information (ENVI)}

According to the Global Reporting Initiative's (2013) Sustainable Development Report Guidelines, the total number of items for disclosure of mandatory environmental accounting information is 34 items in the 12 relevant fields as Table 2:

Table 2

Items for Mandatory Environmental Information Disclosure

\begin{tabular}{llcclcc}
\hline No. & Sectors & $\begin{array}{c}\text { No of items } \\
\text { have to be } \\
\text { disclosed }\end{array}$ & No. & & Sectors & $\begin{array}{c}\text { No of items } \\
\text { have to be } \\
\text { disclosed }\end{array}$ \\
\hline 1 & Material & 2 & 7 & Information on label of products and services & 2 \\
2 & Energy & 5 & 8 & Compliance & 11 \\
3 & Water & 3 & 9 & Transportation & 1 \\
4 & Biodiversity & 4 & 10 & Overall & 1 \\
5 & Emissions & 7 & 11 & Supplier's Review of the Environment & 2 \\
6 & Wastewater and & 5 & 12 & Environmental complaints mechanism & 1 \\
\hline
\end{tabular}


To assess the extent of disclosure of environmental accounting information, information regarding the criteria are scored in Table 3.

\section{Table 3}

Method for Assessing Disclosure Levels of Environmental Information

\begin{tabular}{lc}
\hline \multicolumn{1}{c}{ Level of information disclosure } & Score \\
\hline Publication information is both quantitative and qualitative form & 4 \\
Only qualitative, non - quantitative disclosure & 3 \\
Quantitative information both in object and value, no qualitative information & 2 \\
Quantitative information on the value, no object and no qualitative information & 1 \\
No information disclosure & 0 \\
\hline
\end{tabular}

The disclosure index is calculated according to the weighted approach, depending on the quality of the information provided to assess the score for each item, then averaged for each field and calculated environmental accounting information disclosure index. The formula is as follows: The level of information disclosure of firms $\mathrm{X}=\frac{\sum_{i=1}^{34} Y i}{34}$ ( $Y i$ is the score of information item $i$ published by firm $X$ ). Similarly, research has calculated the level of information disclosure by field.

\section{- Financial performance and control variables}

To measure financial performance, the study used an accounting-based measure and a market-based metric, and two indicators representing financial performance were ROA $\left(\mathrm{ROA}=\frac{\text { Profit apter tax }}{\text { Total Assets }}\right)$ and Tobin'q (TBQ $\left.=\frac{\text { Liabilities }+ \text { Market price of equity }}{\text { Total Assets }}\right)($ Ahmed \& Habib, 2015). The choice of these two indicators is because they are the ones most practiced in previous studies.

Control variables include: Business Size (SIZE); Financial leverage (LEV); Listing period (AGE); Independent Auditing (AUD) are measured and presented in Table 4, below:

\section{Table 4}

Measurement of Control Variables

\begin{tabular}{lll}
\hline Code & \multicolumn{1}{c}{ Control Variable } & \multicolumn{1}{c}{ Measurement } \\
\hline SIZE & Firm size & Log (Total Assets) \\
LEV & Financial leverage & Total long-term debt divided by total assets \\
AGE & Listing period & Number of years from the beginning of listing to the end of 2017 \\
AUD & Independent auditors & $=1$, independent auditor of Big $4 ;=0$, the rest \\
\hline
\end{tabular}

To examine the relationship between the level of disclosure of environmental accounting information and the financial performance of an enterprise, we study the following regression models: (i) Financial efficiency is a dependent variable, Environmental accounting disclosures and four control variables are independent variables. (ii) Additional latency factors are used to assess the impact of prior year disclosure of environmental accounting information on performance. The study choses a one-year lag (t-1) that was not many years ago due to the inadequate sample size. The research model is written as follows:

$$
\begin{aligned}
& R O A_{j t}\left(T B Q_{j t}\right)=\beta 0+\beta 1 E N V I_{j t}+\beta 2 S I Z E_{j t}+\beta 3 L E V_{j t}+\beta 4 A G E_{j t}+\beta 5 A U D_{j t}+\boldsymbol{\varepsilon}_{j t} \\
& R O A_{j t}\left(T B Q_{j t}\right)=£ 0+£ 1 E N V I_{j t-1}+£ 2 S I Z E_{j t}+£ 3 L E V_{j t}+£ 4 A G E_{j t}+£ 5 A U D_{j t}+£_{j t}
\end{aligned}
$$

\section{Results and Discussion}

\subsection{Descriptive Statistics}

Fig. 1 gives an overview of the level of disclosure of environmental accounting information by listed firms in Vietnam from 2013 to 2017. During the study period, increasing market volatility is not only evidenced by the number of listed firms with disclosure of environmental accounting information (from 
10 firms in 2013 to 105 firms in 2017), but also by indicator level of disclosure of environmental accounting information which is a good sign demonstrating that Vietnam firms are paying attention to the release of information on environmental indicators, especially after the detailed guidance of Circular No. 155/2015/TT-BTC on 06 October 2015. This is shown by the mean value of the environmental accounting disclosure indicators in 2016, 2017 compared to the previous years.

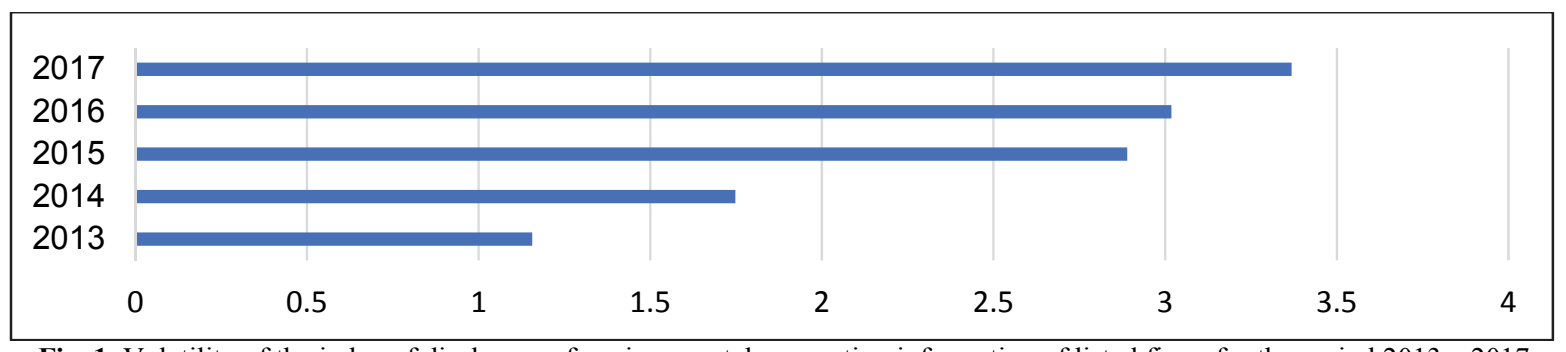

Fig. 1. Volatility of the index of disclosure of environmental accounting information of listed firms for the period $2013-2017$

Table 5

Statistical Analysis

\begin{tabular}{lcccccccc}
\hline & ROA & TBQ & ENVI $_{\mathbf{t}}$ & ENVI $_{\mathbf{t}-1}$ & SIZE & LEV & AGE & AUD \\
\hline Number of Observations & 244 & 244 & 244 & 139 & 244 & 244 & 244 & 244 \\
Mean value & .185 & 1.294 & 2.879 & 2.667 & 15.265 & 0.410 & 14.391 & 0.405 \\
Standard Deviation & .091 & 1.228 & 2.705 & 2.605 & 5.184 & 0.317 & 7.059 & 0.419 \\
Minimum value & -.349 & .004 & 1.008 & 1.105 & 10.329 & 0.219 & 9.865 & 0.000 \\
Maximum value & .735 & 6.652 & 3.687 & 3.287 & 18.327 & 0.683 & 17.710 & 1.000 \\
\hline
\end{tabular}

Table 5 presents basic statistics describing parameters of independent variables and dependent variables. According to Tauchen (1986), condition for estimation of reliability for performing regression analysis is $n>200$. According to Hair et al. (2011), there should be 15-20 observations for a variable to be estimated. Combined with these principles, the sample size chosen by the authors with 244 observations is reasonable. The results insure the reliability. The results in Table 5 show that the level of environmental accounting information disclosure is 2.879 and it ranges from 1.008 to 3.687. The size of the business ranges from 10.329 to 18.327 , indicating that the size of the firms in the sample differs widely. The period of listing on the stock market is 14.391 years on average and fluctuates from 9.865 to 17.710 , which proves that the listed firms in the sample are not too young.

\subsection{Evaluation of Correlation between Variables}

Table 6 presents the results of the correlation coefficient test between the variables and the results of the multicollinearity test. The purpose of the correlation analysis is to examine the tendency of the relationship between independent variables and dependent variables in the model. The previous year's and the year's levels of disclosure of environmental accounting information are positively correlated with ROA and TBQ, which means that the higher the level of disclosure of environmental accounting information, the higher the level of financial efficiency in both present and future. However, to confirm whether the results are accurate or not, we need to conduct multivariate regression analysis.

Table 6

Correlation and Multicollinearity Test

\begin{tabular}{|c|c|c|c|c|c|c|c|c|c|c|}
\hline & ROA & TBQ & ENVI $_{t}$ & ENVI $_{t-1}$ & SIZE & LEV & AGE & AUD & VIF (t) & $\begin{array}{l}\text { VIF } \\
(t-1)\end{array}$ \\
\hline ROA & 1 & & & & & & & & - & - \\
\hline TBQ & 0.512 & 1 & & & & & & & - & - \\
\hline ENVI $_{t}$ & 0.065 & 0.134 & 1 & & & & & & 2.125 & - \\
\hline ENVI $_{t-1}$ & 0.624 & 0.467 & 0.036 & 1 & & & & & - & 2.013 \\
\hline SIZE & -0.210 & 0.007 & -0.452 & -0.089 & 1 & & & & 1.217 & 1.834 \\
\hline LEV & -0.543 & 0.108 & 0.137 & -0.156 & 0.133 & 1 & & & 1.716 & 1.916 \\
\hline AGE & 0.567 & 0.215 & 0.228 & 0.167 & 0.189 & 0.154 & 1 & & 1.912 & 1.813 \\
\hline AUD & 0.289 & 0.241 & 0.185 & 0.112 & 0.221 & 0.143 & 0.127 & 1 & 1.713 & 1.853 \\
\hline
\end{tabular}


Table 6 also shows the results of the multicollinearity test, where the results show that at the same time, the correlated pairs are less than 0.8 and the VIF of the independent variable is less than 5, which proves that there is not multicollinearity. In addition, in order to increase the reliability of the regression results, the study conducted to examine whether there was a change in variance in the research model through the use of the White's General test. The test results show that the P-value is greater than 0.05 , so with a significance level of $5 \%$ the $\mathrm{H}_{0}$ hypothesis on the uniformity of the variance is acceptable. That is, the pattern does not exist in the phenomenon of variance. With the above analysis, we assert the appropriate research data to perform multivariate regression analysis to examine the relationship between social responsibility and financial efficiency.

\subsection{Discussions}

(i) The relationship between the level of disclosure of environmental accounting and the financial performance of the current year.

Table 7 presents the results of regression using the least squares (OLS), fixed effects model (FEM) and random effects model (REM). The results show that there are differences between the three methods. The model is best suited for the case where ROA is a dependent variable and where TBQ is a dependent variable. Research conducted the Breusch-Pagan Lagrange test; Hausman test; and F_test, the test results are as follows:

Table 7

Regression Results - the case does not consider latency factor

\begin{tabular}{lrrrrrr} 
& \multicolumn{3}{c}{ ROA } & \multicolumn{3}{c}{ TBQ } \\
\cline { 2 - 7 } & OLS & FEM & REM & OLS & FEM & REM \\
\hline ENVI & 0.253 & 0.325 & 0.254 & 0.651 & 0.287 & 0.428 \\
& $(.0341)$ & $(.0123)$ & $(.0242)$ & $(.0761)$ & $(.1681)$ & $(.1774)$ \\
SIZE & -0.324 & -0.743 & 0.262 & 0.568 & -0.764 & 0.296 \\
& $(.0015)$ & $(.0054)$ & $(.0074)$ & $(.0031)$ & $(.0037)$ & $(.0017)$ \\
LEV & -0.265 & 0.098 & -0.454 & -0.860 & 0.165 & -0.197 \\
& $(.0061)$ & $(.0378)$ & $(.0028)$ & $(.0056)$ & $(.0065)$ & $(.0037)$ \\
AGE & 0.328 & 0.187 & 0.178 & 0.287 & 0.276 & 0.546 \\
& $(.0075)$ & $(.0038)$ & $(.0350)$ & $(.0076)$ & $(.0012)$ & $(.0067)$ \\
AUD & 0.982 & 0.251 & 0.584 & 0.186 & 0.441 & 0.427 \\
Number of Obs & $(.0073)$ & $(.0029)$ & $(.0095)$ & $(.0028)$ & $(.0045)$ & $(.0082)$ \\
Constant & 244 & 244 & 244 & 244 & 244 & 244 \\
Adj R-squareds & 0.316 & 0.343 & 0.425 & 0.532 & 0.635 & 0.712 \\
\hline & 0.3245 & 0.3427 & 0.3546 & 0.4235 & 0.4476 & 0.4985 \\
\hline
\end{tabular}

- ROA is a dependent variable: For the results of the Breusch-Pagan Lagrange test, the hypothesis $\mathrm{H}_{0}$ is accepted (Prob $=1.0000)$ thus the pooled OLS model is more appropriate than the REM model. For the Hausman test, rejecting the hypothesis $\mathrm{H}_{0}(\mathrm{Prob}=0.0444)$ means that the FEM model is more appropriate than the REM model. However, based on F-test results (Prob $=0.4620)$, it is also assumed that the fit model is pooled OLS. Thus, the final fit model to measure this relationship is the pooled OLS model, with a $1 \%$ significance level. The results in Table $7,($ Sig. $=0.0341<0.05)$ show that the level of disclosure of environmental accounting information affects the current year's ROA.

- TBQ is a dependent variable: For the results of the Breusch-Pagan Lagrange test, showing the rejection of the null hypothesis (Prob $=0.0000)$, the REM model is more appropriately modeled as pooled OLS. Similarly, for the Hausman test, the test also rejected the hypothesis $\mathrm{H}_{0}(\mathrm{Prob}=0.0000)$ and the FEM model was more appropriate than the REM model. At the same time, the F-test also shows that the FEM model is a suitable model (Prob $=0.0000)$. Therefore, the appropriate model for measuring this relationship is the FEM model. The results in Table 7 (Sig. $=0.1681>0.05$ ) show that the level of disclosure of environmental accounting information has no impact on the current year's TBQ. Thus, the level of disclosure of environmental accounting information of enterprises listed on the Vietnam securities market influences the financial performance according to the current year's accounting. There is a relationship between the level of disclosure of environmental accounting information and the financial performance of the current year. This result is contrary to the studies of Isanzu and Fengju 
(2016), Nelling and Webb (2009) and Ho et al., 2017. However, this is explained by the sensitivity of the Vietnamese stock market with financial accounting information disclosed.

(ii) The relationship between the level of disclosure of environmental accounting and the financial performance of the following year

To examine the relationship between the level of toxicity disclosed by environmental accounting information and the financial performance of the following years, the study performed a multivariate regression analysis with dependent variables: ROA, TBQ and t-test. The results of the regression analysis are presented in Table 8. Similarly, the study also conducted Breusch-Pagan Lagrange test; Hausman test; and $\mathrm{F}$ _test, to choose the most suitable model to measure this relationship. The test results indicate that, in the case of ROA as a dependent variable, the OLS model is best suited, in the case of TBQ as the dependent variable, the FEM model is sub-merged with the significance level of 5\%. The results in Table 8 show that Sig. $=0.0123$ and Sig. $=0.0109<0.5$, there is a relationship between the level of disclosure of previous year's accounting information and the financial performance of the following year. As a result, the level of disclosure of environmental accounting information by enterprises listed on the Vietnamese securities market affects the financial performance according to the accounting and market of the following year. This result is consistent with some studies (Isanzu \& Fengju, 2016; Nelling \& Webb, 2009; Ho et al., 2017). This shows that the clearer, more detailed and transparent disclosure of environmental accounting information is more conducive to the future financial performance of the business.

Table 8

$\underline{\text { Regression Results - The case considers the latency factor }}$

\begin{tabular}{|c|c|c|c|c|c|c|}
\hline & \multicolumn{3}{|c|}{ ROA } & \multicolumn{3}{|c|}{ TBQ } \\
\hline & OLS & FEM & REM & OLS & FEM & REM \\
\hline ENVI $_{t-1}$ & $\begin{array}{c}0.546 \\
(.0123)\end{array}$ & $\begin{array}{c}0.324 \\
(.0114)\end{array}$ & $\begin{array}{c}0.865 \\
(.0176)\end{array}$ & $\begin{array}{c}0.165 \\
(.0164)\end{array}$ & $\begin{array}{c}0.186 \\
(.0109)\end{array}$ & $\begin{array}{c}0.254 \\
(.0433)\end{array}$ \\
\hline SIZE & $\begin{array}{l}-0.643 \\
(.1653)\end{array}$ & $\begin{array}{l}-0.146 \\
(.0186)\end{array}$ & $\begin{array}{c}0.864 \\
(.0143)\end{array}$ & $\begin{array}{c}0.175 \\
(.0197)\end{array}$ & $\begin{array}{l}-0.185 \\
(.0165)\end{array}$ & $\begin{array}{c}0.654 \\
(.0187)\end{array}$ \\
\hline LEV & $\begin{array}{l}-0.186 \\
(.0011)\end{array}$ & $\begin{array}{c}0.086 \\
(.0187)\end{array}$ & $\begin{array}{l}-0.413 \\
(.0342)\end{array}$ & $\begin{array}{c}-0.175 \\
(.0543)\end{array}$ & $\begin{array}{c}0.178 \\
(.0197)\end{array}$ & $\begin{array}{l}-0.197 \\
(.0165)\end{array}$ \\
\hline AGE & $\begin{array}{c}0.148 \\
(.0198)\end{array}$ & $\begin{array}{c}0.087 \\
(.0023)\end{array}$ & $\begin{array}{c}0.186 \\
(.0190)\end{array}$ & $\begin{array}{c}0.581 \\
(.0123)\end{array}$ & $\begin{array}{c}0.276 \\
(.0087)\end{array}$ & $\begin{array}{c}0.286 \\
(.0017)\end{array}$ \\
\hline AUD & $\begin{array}{c}0.197 \\
(.0065)\end{array}$ & $\begin{array}{c}0.286 \\
(.0017)\end{array}$ & $\begin{array}{c}0.325 \\
(.0086)\end{array}$ & $\begin{array}{c}0.372 \\
(.0026)\end{array}$ & $\begin{array}{c}0.327 \\
(.0098)\end{array}$ & $\begin{array}{c}0.154 \\
(.0036)\end{array}$ \\
\hline Number of Obs & 139 & 139 & 139 & 139 & 139 & 139 \\
\hline Constant & 0.165 & 0.154 & 0.254 & 0.387 & 0.429 & 0.387 \\
\hline Adj R - squareds & 0.4273 & 0.3268 & 0.3197 & 0.4123 & 0.4643 & 0.4017 \\
\hline
\end{tabular}

(iii) Considering the financial effect between the company disclosing the environmental accounting information and the company not disclosing the environmental accounting information

The study examined the difference in financial performance between the two groups of firms: the group disclosed environmental accounting information and the group did not disclose environmental accounting information. The results are presented in Table 9, which show the financial performance of each group and the results of the t-test.

Table 9

Group financial performance and Bartlett's test for equal variances

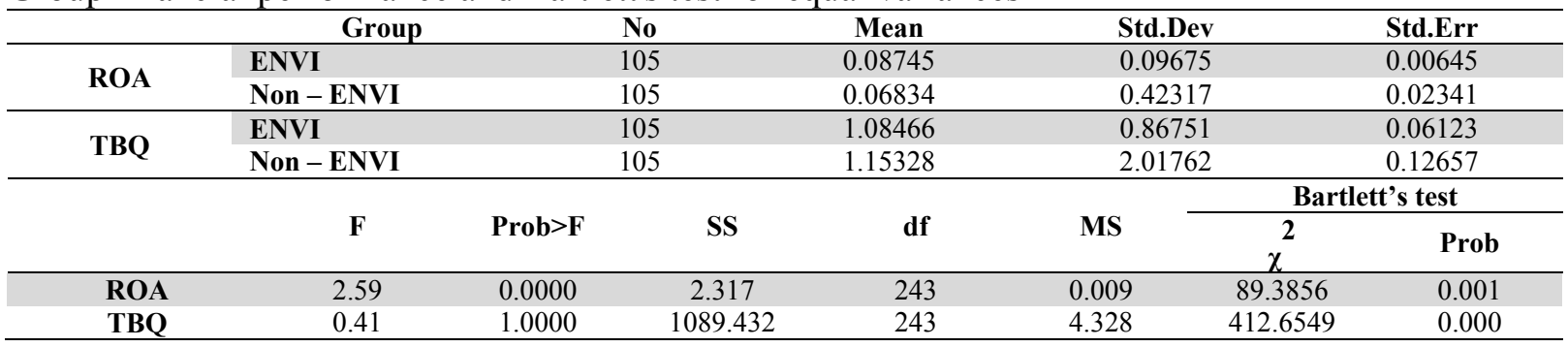


- If accounting for ROA: The mean value for group statistics of listed firms with environmental accounting disclosures (0.087) is higher than for firms Non-disclosure of environmental accounting information (0.068). At the same time, $\mathrm{t}$-test results show that $\mathrm{P}$-value $=0.000<0.05$. Thus, the hypothesis $\mathrm{H}_{0}$ is rejected and accepts the alternative hypothesis. This means that there was a statistically significant difference in ROA among listed firms with environmental accounting information disclosure and listed firms without disclosure of environmental accounting information.

- If we look at market-based financial performance (TBQ): The mean value for group statistics of listed firms with environmental accounting disclosures (1.084) is lower than for firms Non-disclosure of environmental accounting information $(1,153)$. At the same time, $t$-test results show that $\mathrm{P}$-value $=1.000 \mathrm{>}$ 0.05 . Thus, the null hypothesis is accepted, which means that there is no statistically significant difference in TBQ between listed firms with publicly available environmental accounting information and unlisted firms. Environmental accounting information. Thus, when the listed company performs the disclosure of environmental accounting information in a detailed and transparent manner, it enhances the image, increases the value of the brand, promotes morale of employees, enhances the productivity, resulting in reduced transaction costs to obtain external funding.

\section{Conclusion and Recommendations}

The research results have indicated the importance of environmental accounting information disclosure of enterprises in the long-term business strategy. Highly effective firms are often among the top firms in the industry that are well-regarded for their environmental responsibility, as demonstrated by adequate and detailed disclosure of information related to the environment. The disclosure of environmental accounting information is a way for businesses to enhance their image and reputation with stakeholders, especially in the integration trend when developed countries are very interested in green growth and sustainable development. However, the situation shows that the accounting work and information disclosure related to the environment have not been properly received attention by Vietnam firms doing business under of the model parent company - subsidiary company. Therefore, in the coming time, businesses need to strengthen the solution to improve environmental accounting to support the disclosure of information. From the research results, the research team proposed some recommendations to the Vietnam as follows:

First, the need to raise awareness of corporate environmental responsibility and the benefits of disclosing detailed environmental accounting information to the financial performance of the business. Some businesses say that if they focus on environmental protection activities, transparency of environmental accounting information is costly, reducing profits, it is a misconception. The empirical results of the study have shown that the level of disclosure of environmental accounting information affects the economic efficiency of enterprises both now and in the future. Therefore, the disclosure of environmental accounting information is not only to comply with environmental law, avoid legal complications but also to improve the image and increase the financial efficiency of the business.

Second, in the Vietnamese context, the reporting of primary environmental accounting information is still voluntary and free of any general pattern, with only large firms reporting responsibility. The number of firms reporting social responsibility is very low. Research results are the basis for encouraging organizations to change views when making annual reports as well as the content of disclosure in their annual report should not be too focused on the indicators. Financial results achieved during the year that ignored the environmental performance achieved. Because, together with the trend of green development of the world, investors are more interested in the information related to the implementation of corporate social responsibility. Consequently, with the implementation of environmental responsibility, the disclosure of this information to investors is also a way to attract their attention.

Third, the results also show that, in addition to the level of disclosure of environmental accounting information, other factors such as business size, financial leverage, listing period, independent auditing also affect the business performance of the business. Therefore, in order to achieve economic efficiency in the period, enterprises should consider, coordinate and pay attention to many factors in order to 
achieve the best economic growth while ensuring economic growth, medium ensure sustainable development and enhance the image of enterprises in the market.

Based on the quantitative and qualitative research methodology, the team assessed the impact of the level of disclosure of environmental accounting information on the financial performance of the business. The results indicate that the level of disclosure of environmental accounting information affects the financial performance of businesses both now and in the future. At the same time, the study also found the relative difference in financial performance between two groups of enterprises disclosing environmental accounting information and not disclosing environmental accounting information. From the research results, the team has made several recommendations to promote the level of disclosure of environmental accounting information in the future. The article has enriched the sources of research on environmental accounting as well as contributed to the disclosure of environmental accounting information in the future. However, research is limited to two financial measures and four control variables, while still using other indicators to test this relationship, further limiting the sample also makes sense. Dependency of affected results. Nevertheless, we consider these to be suggestive for further research in the future.

\section{References}

Ahmed, T., \& Habib, F. (2015). Does CSR enhance profitabilty?: Evidence from an emerging economy. International Journal of Engineering Technology, Management and Applied Sciences, 3, 424-429.

Al-Tuwaijri, S.A., Christensen, T.E., \& II, K.E.H. (2004). The relations among environmental disclosure, environmental performance, and economic performance: a simultaneous equations approach. Accounting, Organizations and Society, 29(5-6), 447-471.

Ali, M. J., Ahmed, K., \& Henry, D. (2004). Disclosure compliance with national accounting standards by listed firms in South Asia. Accounting and Business Research, 34(3), 183-199.

Barakat, F.S.Q., Pérez, M.V.L., \& Ariza, L.R. (2015). Corporate social responsibility disclosure (CSRD) determinants of listed firms in Palestine (PXE) and Jordan (ASE). Review of Managerial Science, 9(4), 681-702.

Boaventura, J. o. M. c. G., Silva, R. S. d., \& Bandeira-de-Mello, R. (2012). Corporate Financial Performance and Corporate Social Performance: Methodological Development and the Theoretical Contribution of Empirical Studies. Paper presented at the R. Cont. Fin. - USP, São Paulo.

Waddock, S. A., \& Graves, S. B. (1997). The corporate social performance-financial performance link. Strategic management journal, 18(4), 303-319.

Chiu, T. K., \& Wang, Y. H. (2015). Determinants of social disclosure quality in Taiwan: An application of stakeholder theory. Journal of business ethics, 129(2), 379-398.

Dowling, J., \& Pfeffer, J. (1975). Organizational legitimacy: Social values and organizational behavior. Pacific sociological review, 18(1), 122-136.

Guthrie, J., \& Parker, L. D. (1989). Corporate social reporting: a rebuttal of legitimacy theory. Accounting and business research, 19(76), 343-352.

Hitt, M. A., Freeman, R. E., \& Harrison, J. S. (2017). A Stakeholder Approach to Strategic Management. Published Online: 26 Nov 2017: The Blackwell Handbook of Strategic Management.

Horváthová, E. (2012). The impact of environmental performance on firm performance: Short-term costs and long-term benefits?. Ecological Economics, 84, 91-97.

Isanzu, J., \& Fengju, X. (2016). Impact of Corporate Social Responsibility on Firm's Financial Performance: The Tanzanian Perspective. Journal on Innovation and Sustainability, 7(1), 18-27.

Jamil, C. Z. M., Mohamed, R., Muhammad, F., \& Ali, A. (2015). Environmental management accounting practices in small medium manufacturing firms. Procedia-Social and Behavioral Sciences, 172, 619-626.

Hair, J. F., Ringle, C. M., \& Sarstedt, M. (2011). PLS-SEM: Indeed a silver bullet. Journal of Marketing theory and Practice, 19(2), 139-152.

Magness, V. (2006). Strategic posture, financial performance and environmental disclosure: An empirical test of legitimacy theory. Accounting, Auditing \& Accountability Journal, 19(4), 540-563. 
Majeed, S., Aziz, T., \& Saleem, S. (2015). The effect of corporate governance elements on corporate social responsibility (CSR) disclosure: An empirical evidence from listed companies at KSE Pakistan. International Journal of Financial Studies, 3(4), 530-556.

Moore, G. (2001). Corporate social and financial performance: An investigation in the UK supermarket industry. Journal of Business ethics, 34(3-4), 299-315.

Nelling, E., \& Webb, E. (2009). Corporate social responsibility and financial performance: the "virtuous circle" revisited. Review of Quantitative Finance and Accounting, 32(2), 197-209.

Nguyen, D.P.A., \& Tran, T.B. (2017). Reality and Factors Affecting the Levels of Disclosure of Social Responsibility Information of Listed Enterprises in Vietnam's Stock Market. Paper presented at the Proceedings of National Workshop: Research and Training Accounting and Auditing of Vietnamese Universities according to international standards, National Economics University.

Nguyen, D.H. (2016). Factors affecting the level of financial information disclosure of firms doing business under of the model parent company-subsidiary firms. Kinh tế \& Phát triển, 224(2).

Nguyen, L. S., Tran, M. D., Nguyen, T. X. H., \& Le, Q. H. (2017). Factors Affecting Disclosure Levels of Environmental Accounting Information: The Case of Vietnam. Accounting and Finance Research, 6(4), 255.

Nguyen, L. S., Tran, T. H., \& Nguyen, T. N. (2018). Factors Affecting Disclosure Levels of Environmental Accounting Information: The Case of Vietnam firms doing business under of the model parent company - subsidiary company. Paper presented at the The 5thIBSM International Conference on Business, Management and Accounting 19-21 April 2018., Hanoi University of Industry, Viet Nam.

Ting, N. I. (2017). Disclosure of the Environmental Accounting Information Research. DEStech Transactions on Economics, Business and Management, (eced).

Poddi, N. C. L., \& Vergalli, S. (2016). Corporate Social Responsibility and Firms' Performance: a Strategic Graphical Analysis. Journal of International Business and Economics, 4(1), 1-12.

Qiu, Y., Shaukat, A., \& Tharyan, R. (2016). Environmental and social disclosures: Link with corporate financial performance. The British Accounting Review, 48(1), 102-116.

Simpson, W. G., \& Kohers, T. (2002). The link between corporate social and financial performance: Evidence from the banking industry. Journal of business ethics, 35(2), 97-109.

Tauchen, G. (1986). Finite state markov-chain approximations to univariate and vector autoregressions. Economics letters, 20(2), 177-181.

Ho, V.T., Ho, T.V.A \& Nguyen, T.C. (2017). The corporate environmental responsibility and corporate financial performance: evidences from Vietnamese listed firms. Paper presented at the Proceedings of ICUEH2017: International conference of University of Economic Ho Chi Minh City: Policies and sustainable economic development., HCMC, Vietnam, September 28, 2017.

Ullmann, A. A. (1985). Data in search of a theory: A critical examination of the relationships among social performance, social disclosure, and economic performance of US firms. Academy of management review, 10(3), 540-557.

Yang, L.-H., \& Liangb, X.-T. (2017). Study on the Influencing Factors of Environmental Accounting Information Disclosure. Paper presented at the International Conference on Economics, Management Engineering and Marketing (EMEM 2017).

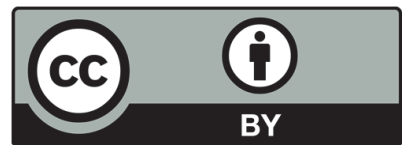

(C) 2019 by the authors; licensee Growing Science, Canada. This is an open access article distributed under the terms and conditions of the Creative Commons Attribution (CC-BY) license (http://creativecommons.org/licenses/by/4.0/). 